\title{
An Empirical Investigation of Chinese Online Consumer Ethics
}

\author{
Dong Lu', Ye Tian² \\ ${ }^{1}$ School of Business, Sichuan Normal University, Chengdu, China \\ ${ }^{2}$ School of Economics and Management, Southwest Jiaotong University, Chengdu, China \\ Email: dlu@sicnu.edu.cn, ye.tian@my.switu.edu.com
}

Received 10 September 2015; accepted 23 October 2015; published 27 October 2015

Copyright (C) 2015 by authors and Scientific Research Publishing Inc.

This work is licensed under the Creative Commons Attribution International License (CC BY). http://creativecommons.org/licenses/by/4.0/

(c) $\underset{\mathrm{EY}}{\mathrm{P}}$ Open Access

\begin{abstract}
In the Chinese online consuming context, this study proposes 12 hypotheses and constructs a conceptual model to investigate the relationship between ethical ideologies and unethical behaviors. The empirical results successfully supported these hypotheses and clearly explained the mechanism that the three aspects of ethical ideologies (Idealism, Relativism and Machiavellianism) influenced four typical online unethical behaviors in varying degree. And this study in the online context makes contribution to the researches with topic of unethical behaviors. Besides, this study also brings managerial suggestions for practice.
\end{abstract}

\section{Keywords}

Ethical Ideologies, Online Unethical Behavior, Ethics

\section{Introduction}

China has become one of the most important markets for online business. Just on the date of $11^{\text {th }}$ November 2014, there was a turnover of approximate 9.3 billion US dollars from Tmall.com, a Chinese leading e-commerce platform [1]. Companying with the booming of Chinese online business market, an increasing number of online unethical behaviors have brought numerous drawbacks to the public and have produced a variety of adverse effects to the society. And the online unethical behaviors, including disturb order behavior, self-serving malevolently behavior, forbearing injurious behavior and copyright infringing behavior, also generate much threat to the emerging market. In the market economy, the buyers and the sellers always generate business ethics issues [2]. And business ethics has aroused widespread concern by the theorists and industries [3]. For the continuous development of the online business, many problems are concerned about the consumers' online ethical behaviors. Most of previous studies focused on these issues only on the sellers' side, and somehow neglected the 
important role of buyers in the consuming process. However, each point in the consuming process, such as acquiring, using and disposing the service or products, contains certain ethical ingredients. Therefore, it is necessary to understand the mechanism of online unethical behaviors to be formed. Because if we know well the reason why consumers engage in unethical behaviors, we can radically reduce or even eliminate such unethical behaviors [2]. And taking consideration of the Chinese culture and traditions, this study constructs a model to explain the effects of ethical ideologies on online unethical behaviors.

\section{Literature Review}

\subsection{Ethical Ideologies}

The ethical ideologies can be divided into three aspects, namely, Idealism, Relativism and Machiavellianism. Idealism rooted in the Skopos Theory, representing the individuals' concern for the welfare of others, and emphasizing to avoid damage as well [4]. Moreover, highly idealistic individuals are normally with high degree of moral standards, such situation is also known as the obligation of moral. And Idealism reflects the fact that the individuals merely pay attention to the behavior itself right or wrong, but do not think about the results produced by the behavior. When the individuals with high Idealism solve moral dilemmas for absolute right or wrong, the individuals always ignore the influence made from other people or the society as a whole [5]. Furthermore, the Idealists emphasize the inner rationality of decision about the behavior and focus on following the moral rules [6]. So in general, Idealism makes individuals concern much of the rationality of their behaviors, advocate making moral decisions depending on their personal ideal, and insist that people should not hurt others in any situation or any time.

Relativism is the result of deontology, on behalf of individuals' refuse for the constraint of common ethical norm [4]. And Relativism refers to such a personal tendency that the individuals' decision-making processes are based on the specific circumstances or are based on the prospective and possible results [5]. The relativists think the change of norm is due to the change of time or other situational variables. They also oppose to widely use the moral rules, and only make the moral judgment depending on the behavior results [7]. Moreover, the relativists do not accept the unity of moral standard when they are making moral decisions [8], and they pay more attention to the important environmental factors, but pay less attention to the code of ethics which may be violated [9]. Hence, the relativists would like to make moral judgments that rely on the behavior [10]. Since in traditional Chinese culture, people believe that all things are not absolutely independent of relevance, and are depended on each other's existence, so Relativism can be considered as one of the main characters of Chinese people.

Machiavellianism is named after Niccolo Machiavelli, who had the thought that people should achieve their goals by hook or by crook. In Machiavellianism, the criterion of thoughts normally indicates that the failure attaches great importance, the emotional distance be paid attention to maintain, it should be believed that the results can justify the means, and people should achieve their goals by using the moral means to manipulate others [11]. The Machiavellians have a cold detached spirit that they are less affected by the emotions of others, and they always attempt to retain their face in any embarrassing environment [12]. So Machiavellianism implies that the individuals can use all means to achieve their own ends. And Singhapakdi indicated that it can apply the concept of Machiavellianism to research the consumer ethic issues [13].

\subsection{The Online Consumer Unethical Behavior}

The online consumer unethical behavior occurs in the network circumstance, where online consumers have the motivations based profits or emotions to produce such behaviors which may cause adverse effects to the public and may not be normally acceptable in the public [14]. The online consumer unethical behavior has three features. The first one is Group Polarization, which is defined as that the individual tends to favor the more extreme ideology and ideological direction that has been recognized by the group [15]. This means the group's decisionmaking will be more extreme than the individual's decision. And the extreme decision contains two trends, respectively, the supreme adventure or the supreme caution. Moreover, the group's decision decisions are usually close to the adventure. That is to say, compared with the individual's alone action, the group's action prefer to make adventures and produce irrational behaviors, such as publishing the extremist rhetoric, jointly attack a target and so on. Due to Lee's study, the Internet environment creates the condition to boost Group Polarization [16]. The second one is Deindividuation, which is explained as that the individual should ignore its personal 
identity and sense of responsibility in the group, and no longer express itself as a single person [17]. And in the Internet environment, there is a huge population. The features of the Internet, like the weak controllability, increase the difficulty to identify the individual's responsibility. Therefore, Deindividuation is a very common phenomenon on the Internet. The third one is Rational Egoism, which means self-interest is human nature and self-interest is not considered to change according to the online or offline environment [18]. That is to say, people with Rational Egoism normally consider the pursuit of interests is significant to them. And in such context, the online consumer unethical behavior can be predicted by Rational Egoism. For instance, the individual just unreasonably gives poor rating for the merchant or arbitrarily cancel orders without any reason.

It is widely accepted that the offline consumer unethical behavior is mainly due to the interests driven [19]. However, the online consumer unethical behavior is more significantly affected by the emotions [20]. Zeng et al. defined the four dimensions of the online consumer unethical behavior. Specifically, they are the disturb order behavior, the self-serving malevolently behavior, the forbearing injurious behavior and the copyright infringing behavior [14]. Due to the impact of Group Polarization and Deindividuation, the majority of the online consumer unethical behavior is triggered prevalently depends on the generating of emotions. And in accordance with Rational Egoism, some other online consumer unethical behavior can be driven by interests. More precisely speaking, the disturb order behavior is a typical emotion-oriented behavior, which is significantly motivated by the emotional impact. Besides, the self-serving malevolently behavior is a typical interests-oriented behavior, which is significantly motivated by the driving of interests. And moreover, the forbearing injurious behavior and the copyright infringing behavior are both influenced by emotional motivation and pursuit of interests.

\section{Research Hypotheses and the Conceptual Model}

A vast number of previous studies found that the ethical ideologies play an essential role in individuals' behavioral responses [21]. And the ethical ideologies can be measured by Idealism, Relativism and Machiavellianism [7]. Numerous studies indicated that the higher Idealism can reduce the occurrence of the unethical behavior [6]. That is to say, the degree of Idealism is negatively related to the unethical behavior. For the Relativism, considering the fact that Internet has the feature of anonymity which will cause the network identity unrecognizable and make online consumer depersonalization, the different types of consumers can not be distinguished clearly under the network condition. So it should be supposed that Relativism is weakly related with the online unethical behavior. And other studies also stated that Machiavellianism can promote unethical behavior [12]. Therefore, followed the previous theories and literatures, the hypotheses are made in this study:

H1a: Idealism is negatively related to the disturb order behavior.

H1b: Idealism is negatively related to the self-serving malevolently behavior.

H1c: Idealism is negatively related to the forbearing injurious behavior.

H1d: Idealism is negatively related to the copyright infringing behavior.

H2a: Relativism is unrelated to the disturb order behavior.

H2b: Relativism is unrelated to the self-serving malevolently behavior.

H2c: Relativism is unrelated to the forbearing injurious behavior.

H2d: Relativism is unrelated to the copyright infringing behavior.

H3a: Machiavellianism is positively related to the disturb order behavior.

H3b: Machiavellianism is positively related to the self-serving malevolently behavior.

H3c: Machiavellianism is positively related to the forbearing injurious behavior.

H3d: Machiavellianism is positively related to the copyright infringing behavior.

Based on the hypotheses, the conceptual model is generated (see Figure 1).

\section{Empirical Study}

\subsection{Questionnaire Design and Pretest}

For the independent variables, we used Forsyth's Ethics Position Questionnaire (EPQ) to measure Idealism and Relativism [4]. In the EPQ scale, there are 2 parts to test Idealism and Relativism respectively, and there are 10 items in each part. At the same time, we used Hunt and Chonko's MACH IV scale to measure Machiavellianism [11]. And we also used 10 positive items in this scale to measure respondents' degree of Machiavellianism. All the items above were measured by 7-point Likert scale that 1 represents "Extremely disagree” and 7 represents 


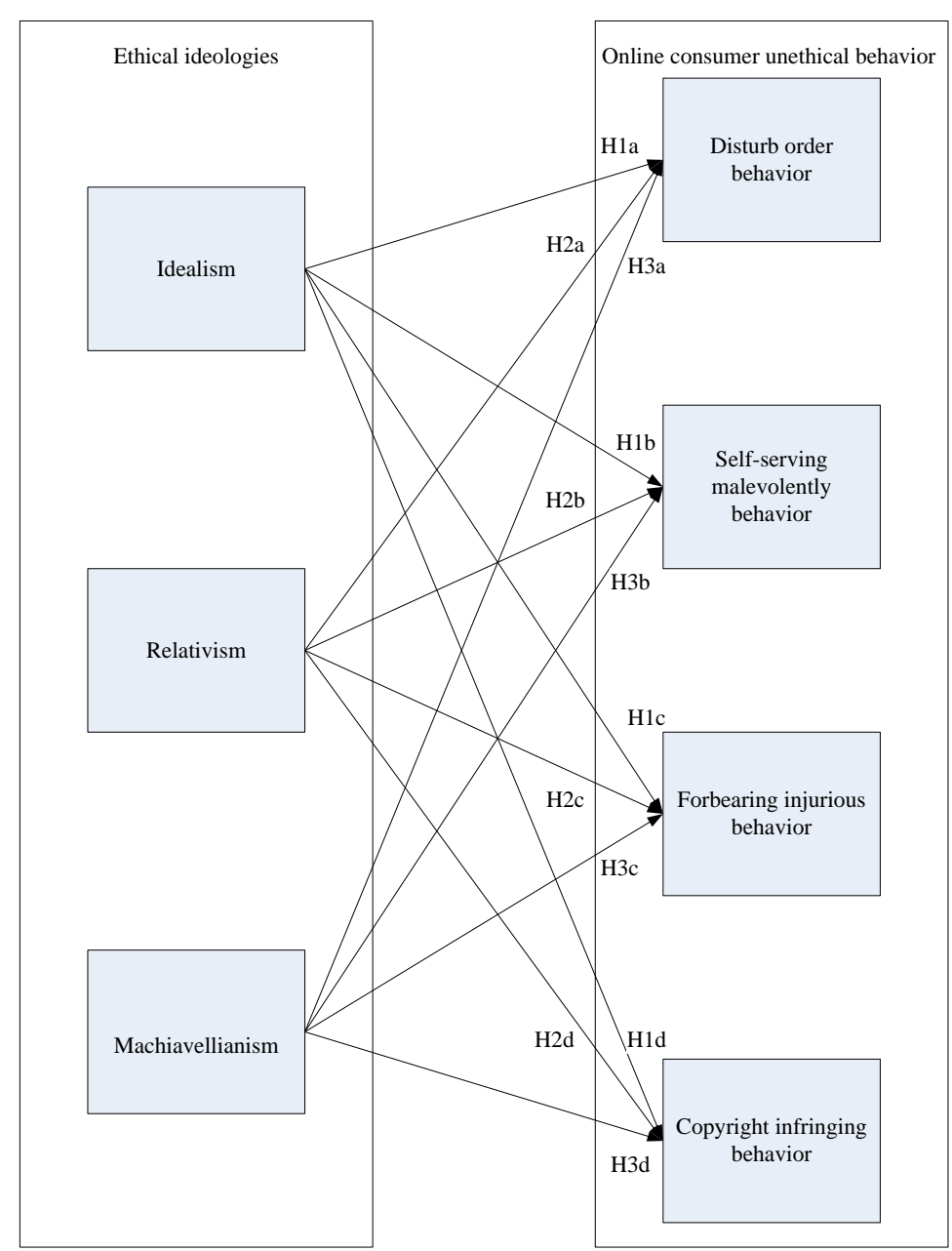

Figure 1. The conceptual model.

"Extremely agree”; and 4 means “Neutral”. For the dependent variables, we used Zeng et al.'s Online Consumer Unethical Behavior Scale (OCUBS) to measure the disturb order behavior (4 items), the self-serving malevolently behavior (4 items), the forbearing injurious behavior (4 items) and the copyright infringing behavior (3 items) [14]. All the 15 items above were measured by 7-point Likert scale that 1 represents "Absolutely wrong" and 7 represents "Absolutely right"; and 4 means "Neutral".

Having completed the questionnaire design, we invited 134 respondents to fill out the questionnaires as the pretest. Besides talking with the respondents to collect their feedbacks about the questionnaire, we also adopted the technique of Corrected Item-Total Correlation (CITC) and Cronbach's $\alpha$ to enhance the scales with a good reliability. Then we deleted the item (the $7^{\text {th }}$ item in MACH IV scale) which has the CITC lower than 0.40 or Cronbach's $\alpha$ lower than 0.70 . After these steps, we made the final scale for this study.

\subsection{Demographic Statistics}

In three months period, we have collected 971 respondents to participate in this study. After check the completeness of the collected questionnaires, finally we got 922 valid data; the effective ratio is $94.95 \%$. The Demographic Statistics is below (see Table 1).

\subsection{Reliability Checks}

According to Hair et al., the Cronbach's $\alpha$ of each latent variable is suggested to be above 0.80 [22]. In this study, we used SPSS 20.0 to check the reliability of the 7 latent variables in the scale. And the results showed 
Table 1. Demographic profile of respondents $(\mathrm{N}=922)$.

\begin{tabular}{|c|c|c|c|}
\hline & & Sample population & Sample proportion \\
\hline \multirow[t]{2}{*}{ Gender } & Male & 530 & $57.50 \%$ \\
\hline & Female & 392 & $42.50 \%$ \\
\hline \multirow[t]{6}{*}{ Age } & Below 18 & 40 & $4.30 \%$ \\
\hline & $18-25$ & 518 & $56.20 \%$ \\
\hline & $26-35$ & 308 & $33.40 \%$ \\
\hline & $36-45$ & 43 & $4.70 \%$ \\
\hline & $46-55$ & 7 & $0.80 \%$ \\
\hline & 56 or above & 6 & $0.70 \%$ \\
\hline \multirow[t]{4}{*}{ Education level } & High school & 148 & $16.10 \%$ \\
\hline & Polytechnic & 253 & $27.40 \%$ \\
\hline & College/University & 486 & $52.70 \%$ \\
\hline & Graduate school & 35 & $3.80 \%$ \\
\hline \multirow[t]{8}{*}{ Occupation } & Retired/Unemployment & 18 & $2.00 \%$ \\
\hline & Full-time student & 301 & $32.60 \%$ \\
\hline & Company staff & 289 & $31.30 \%$ \\
\hline & Government staff & 41 & $4.40 \%$ \\
\hline & Professionals (Teacher/Lawyer/Doctor etc.) & 82 & $8.90 \%$ \\
\hline & Business owner & 22 & $2.40 \%$ \\
\hline & Housewife & 26 & $2.80 \%$ \\
\hline & Others & 143 & $15.50 \%$ \\
\hline \multirow[t]{5}{*}{ Monthly income ${ }^{\mathrm{a}}$} & Below 1000 & 288 & $31.20 \%$ \\
\hline & $1000-3999$ & 454 & $49.20 \%$ \\
\hline & $4000-7999$ & 136 & $14.80 \%$ \\
\hline & 8000 - 11999 & 24 & $2.60 \%$ \\
\hline & 12000 or above & 20 & $2.20 \%$ \\
\hline \multirow[t]{2}{*}{ Marriage } & Single & 297 & $32.20 \%$ \\
\hline & Married & 625 & $67.80 \%$ \\
\hline
\end{tabular}

Note: a. Before tax in Chinese Yuan (RMB).

that each the Cronbach's $\alpha$ is in the acceptable level, which means the reliability checks is successful (see Table 2).

\section{Data Analysis}

There are 4 regression equations and the results are showed below (see Table 3 ).

In the first equation, Disturb order behavior $=(-0.302)$ Idealism $+(-0.065)$ Relativism $+(0.191)$ Machiavellianism, $\mathrm{R}^{2}=0.152$, which means the ethical ideologies explains only $15.2 \%$ of the effects on the online consumers' unethical behaviors and the ethical ideologies has the relatively weaker impact on this behavior. The results also stated that the higher Idealism the individual has, the lower possibility the disturb order behavior the 
Table 2. Reliability of latent variables.

\begin{tabular}{llcc}
\hline Latent variables & & Items & Cronbach's $\boldsymbol{\alpha}$ \\
\hline Ethical ideologies & Idealism & 10 & 0.950 \\
& Relativism & 10 & 0.922 \\
& Machiavellianism & 9 & 0.885 \\
Online consumer unethical behavior & Disturb order behavior & 4 & 0.886 \\
& Self-serving malevolently behavior & 4 & 0.893 \\
& Forbearing injurious behavior & 4 & 0.893 \\
& Copyright infringing behavior & 3 & 0.896 \\
\hline
\end{tabular}

Table 3. Regression analyses.

\begin{tabular}{|c|c|c|c|c|c|}
\hline \multirow{2}{*}{ Dependent variables } & \multicolumn{3}{|c|}{ Independent variables $(\beta)$} & \multirow{2}{*}{$\mathbf{R}^{2}$} & \multirow{2}{*}{$\mathbf{F}$} \\
\hline & Idealism & Relativism & Machiavellianism & & \\
\hline Disturb order behavior & $-0.302^{* *}$ & -0.065 & $0.191^{* *}$ & 0.152 & 18.18 \\
\hline Self-serving malevolently behavior & $-0.383^{* *}$ & -0.044 & $0.180^{* *}$ & 0.212 & 27.20 \\
\hline Forbearing injurious behavior & $-0.378^{* *}$ & 0.046 & $0.162^{* *}$ & 0.188 & 23.43 \\
\hline Copyright infringing behavior & $-0.236 * *$ & 0.062 & $0.195 * *$ & 0.183 & 22.67 \\
\hline
\end{tabular}

Note: ** means $\mathrm{p}<0.001$; * means $\mathrm{p}<0.05$.

individual will produce $(\beta=-0.302$, $\mathrm{p}<0.001)$; and the higher Machiavellianism the individual has, the higher possibility the disturb order behavior the individual will do $(\beta=0.191, \mathrm{p}<0.001)$; but Relativism has no significant impact on the disturb order behavior $(\beta=-0.065, \mathrm{p}>0.05)$. The second equation showed that, Self-serving malevolently behavior $=(-0.383)$ Idealism $+(-0.044)$ Relativism $+(0.180)$ Machiavellianism, $\mathrm{R}^{2}=0.212$. The results indicated that the three aspects of the ethical ideologies exert the relatively strongest influence on the self-serving malevolently behavior, explaining $21.2 \%$ of the effects. It should be mentioned, in this equation Idealism showed the most strongly impact on this kind of online unethical behavior over other online unethical behaviors $(\beta=-0.383, \mathrm{p}<0.001)$. That is to say, the Chinese online consumer with high Idealism would not have the self-serving malevolently behavior. Additionally, Machiavellianism is positively related to the selfserving malevolently behavior $(\beta=0.180, \mathrm{p}<0.001)$ and Relativism has no significant effect $(\beta=-0.044, \mathrm{p}>$ 0.05). In the third equation, $18.8 \%$ of the forbearing injurious behavior was explained by the three aspects of ethical ideologies, and Forbearing injurious behavior $=(-0.378)$ Idealism $+(-0.046)$ Relativism $+(0.162)$ Machiavellianism. The results showed that Idealism has the significantly negative relationship with the forbearing injurious behavior $(\beta=-0.378, \mathrm{p}<0.001)$; Machiavellianism has the significantly positive relationship with the forbearing injurious behavior $(\beta=0.162, \mathrm{p}<0.001)$; and Relativism has no significant effect $(\beta=0.046, \mathrm{p}>$ 0.05). Similarly, in the fourth equation, $18.3 \%$ of the copyright infringing behavior was explained by Idealism ( $\beta$ $=-0.236, \mathrm{p}<0.001)$, Machiavellianism $(\beta=0.195, \mathrm{p}<0.001)$ and Relativism $(\beta=0.062, \mathrm{p}>0.05)$. That is to say, the individual with Idealism would be less likely to have the copyright infringing behavior, but the individual with Machiavellianism would be more likely to do such behavior. Relativism also may play an insignificant role in this behavior. And to sum up, all the hypotheses (H1a-d, H2a-d, and H3a-d) in this study were supported by the empirical data.

Additionally, there was another data analysis used ANOVA technique to compare the Chinese online consumer unethical behavior and ethical ideologies across several demographic categories (see Table 4).

According to the ANOVA results, there were several significant differences between demographic categories. For the gender perspective, the male is more likely to show the disturb order behavior and the self-serving malevolently behavior than the female; besides, the female is more likely to tend to Relativism over the male. For the age perspective, the lower age group (below 25 years old) is more likely to produce some of the online un- 
Table 4. The impact of demographics on Chinese online consumer unethical behavior and ethical ideologies (ANOVA).

\begin{tabular}{|c|c|c|c|c|c|c|c|c|}
\hline & &  & 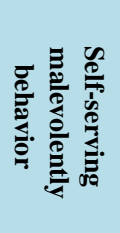 & 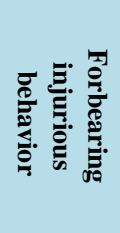 & 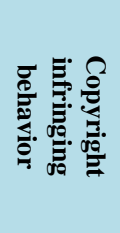 & 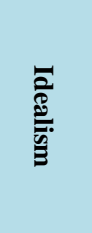 & 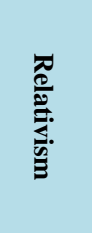 & 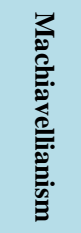 \\
\hline \multirow[t]{2}{*}{ Gender } & Male & $1.56 * b$ & $1.68^{*}$ & 2.08 & 2.38 & 5.35 & $4.35^{*}$ & 3.54 \\
\hline & Female & $1.35^{*}$ & $1.42 *$ & 1.96 & 2.21 & 5.52 & $4.90 *$ & 3.49 \\
\hline \multirow[t]{2}{*}{ Age } & Below 25 & 1.51 & $1.62 *$ & $2.11^{*}$ & $2.39 *$ & $5.13^{*}$ & $4.76^{*}$ & $3.60 *$ \\
\hline & 25 or above & 1.41 & $1.48^{*}$ & $1.91^{*}$ & $2.18^{*}$ & $5.87 *$ & $4.32 *$ & $3.38 *$ \\
\hline \multirow[t]{2}{*}{ Education level } & $\begin{array}{l}\text { Don't access to } \\
\text { College/University }\end{array}$ & 1.51 & 1.59 & 2.03 & 2.31 & 5.41 & $4.77^{*}$ & $3.69 *$ \\
\hline & $\begin{array}{c}\text { Bachelor degree or } \\
\text { above }\end{array}$ & 1.44 & 1.55 & 2.03 & 2.31 & 5.44 & $4.44^{*}$ & $3.81 *$ \\
\hline \multirow[t]{2}{*}{ Occupation } & Non-student & 1.45 & 1.55 & 2.00 & 2.26 & $5.62 *$ & $4.45^{*}$ & 3.51 \\
\hline & Student & 1.51 & 1.61 & 2.09 & 2.40 & $5.02 *$ & $4.86^{*}$ & 3.53 \\
\hline \multirow[t]{3}{*}{ Monthly income ${ }^{\mathrm{a}}$} & Below 1000 & 1.49 & 1.59 & 2.07 & $2.40^{*}$ & $5.12 *$ & $4.89 *$ & $3.51^{*}$ \\
\hline & 1000 - 3999 & 1.46 & 1.53 & 2.06 & $2.37 *$ & $5.39 *$ & $4.72 *$ & $3.71 *$ \\
\hline & 4000 or above & 1.48 & 1.62 & 1.89 & $2.00 *$ & $5.98 *$ & $3.76^{*}$ & $3.02 *$ \\
\hline
\end{tabular}

Note: a. Before tax in Chinese Yuan (RMB); b. It is the mean score of each latent variable; **means $\mathrm{p}<0.001 ; *^{*}$ means $\mathrm{p}<0.05$.

ethical behaviors (the self-serving malevolently behavior, the forbearing injurious behavior and the copyright infringing behavior) and has the higher Relativism and Machiavellianism; however, the higher age group (25 years old and above) possesses a higher degree in Idealism. For the perspective of education level, the more educated group (with a bachelor degree and above) has the higher Machiavellianism but the lower Relativism over its contrary group. For the perspective of occupation, the student group tends to have the higher Relativism but the lower Idealism than the non-student group. And for the perspective of income, when the group has the higher income, the group would have the higher Idealism and be much less likely to produce the copyright infringing behavior. Moreover, the ANOVA results indicated that the degree of Relativism would firstly go down accompanied by the increase of people's income, but after reach a certain point, it will gradually increase up. Conversely, the degree of Machiavellianism would firstly go up accompanied by the increase of people's income, but after reach a certain point, it will gradually drop down.

\section{Discussion and Conclusion}

\subsection{Discussion}

The empirical results bring numerous interesting issues to this topic. First of all, the consumers with the higher Machiavellianism are more prone to have online unethical behaviors; the consumers with the higher Idealism are less prone to have online unethical behaviors; and Relativism has no significant effect on consumers' unethical behaviors. Some previous studies also had the similar findings about the offline consumers' unethical behaviors [23]. The Idealists conventionally use the generalized moral principles as a criterion to judge the right or wrong, and when they are consuming online, their strong self-discipline make themselves not prone to produce the online unethical behaviors. However, the Machiavellian are more concerned about whether the final goal could be achieved or not, but less concerned about whether the process is ethical or unethical. So, the Machiavellian may generate the unethical behaviors in order to obtain benefits or other purposes much easier. Secondly, for the four typical online unethical behaviors, the ethical ideologies influence the self-serving malevolently behavior much more than others. So in practice, it is the way to cultivate people's ethical ideologies foremost to lessen the occurrence of the unethical behaviors. Last but not least, in the particular context, the demographic categories 
could make sense on the online consumer unethical behavior and ethical ideologies. For example, the male Chinese are more prone to disturb order unreasonably or make self-serving behavior malevolently. Therefore, the findings provide a fresh way that using the different segment types of sample in the theoretical model to explain the phenomenon.

\subsection{Conclusion}

Most previous studies about the consumer unethical behavior are in the offline context, which may be different from the online environment [2]. And in this study, we used the sample of Chinese online consumers to build the conceptual model for explaining the relationship between the ethical ideologies and unethical behaviors. The empirical results successfully supported the hypotheses and brought the managerial suggestions for the practice as well. To precise speaking, the merchant can emphasize the damage caused by the unethical behaviors to influence online consumers' decision-making. For example, the merchant should emphasize the punitive measures for the consumer's unethical behaviors in the terms of transaction, and also consider more about the moral factors used in the marketing programs in order to positively influence the online consumers to reduce or even eliminate the unethical behaviors.

\section{Funding}

This study was funded by MOE (Ministry of Education in China) Project of Humanities and Social Sciences (Project No. 15XJC790008).

\section{References}

[1] Shang, X. (2014) The Festival Marketing of Tmall. Com on “Double-Eleven” (11th November). Modern Economic Information, 169-175.

[2] Vitell, S.J., Singhapakdi, A. and Thomas, J. (2001) Consumer Ethics: An Application and Empirical Testing of the Hunt-Vitell Theory of Ethics. Journal of Consumer Marketing, 18, 153-178. http://dx.doi.org/10.1108/07363760110386018

[3] Ferrell, O., Gresham, L.G. and Fraedrich, J. (1989) A Synthesis of Ethical Decision Models for Marketing. Journal of Macromarketing, 9, 55-64. http://dx.doi.org/10.1177/027614678900900207

[4] Forsyth, D.R. (1980) A Taxonomy of Ethical Ideologies. Journal of Personality and Social Psychology, 39, $175-184$. http://dx.doi.org/10.1037/0022-3514.39.1.175

[5] Ferrell, O. and Gresham, L.G. (1985) A Contingency Framework for Understanding Ethical Decision Making in Marketing. Journal of Marketing, 49, 87-96. http://dx.doi.org/10.2307/1251618

[6] Van Kenhove, P., Vermeir, I. and Verniers, S. (2001) An Empirical Investigation of the Relationships between Ethical Beliefs, Ethical Ideology, Political Preference and Need for Closure. Journal of Business Ethics, 32, 347-361. http://dx.doi.org/10.1023/A:1010720908680

[7] Erffmeyer, R.C., Keillor, B.D. and LeClair, D.T. (1999) An Empirical Investigation of Japanese Consumer Ethics. Journal of Business Ethics, 18, 35-50. http://dx.doi.org/10.1023/A:1006025724126

[8] Swaidan, Z., Vitell, S.J. and Rawwas, M.Y. (2003) Consumer Ethics: Determinants of Ethical Beliefs of African Americans. Journal of Business Ethics, 46, 175-186. http://dx.doi.org/10.1023/A:1025068902771

[9] Forsyth, D.R. (1992) Judging the Morality of Business Practices: The Influence of Personal Moral Philosophies. Journal of Business Ethics, 11, 461-470. http://dx.doi.org/10.1007/BF00870557

[10] Hunt, S.D. and Vitell, S. (1986) A General Theory of Marketing Ethics. Journal of Macromarketing, 6, 5-16. http://dx.doi.org/10.1177/027614678600600103

[11] Hunt, S.D. and Chonko, L.B. (1984) Marketing and Machiavellianism. Journal of Marketing, 48, 30-42. http://dx.doi.org/10.2307/1251327

[12] Rawwas, M.Y. (1996) Consumer Ethics: An Empirical Investigation of the Ethical Beliefs of Austrian Consumers. Journal of Business Ethics, 15, 1009-1019. http://dx.doi.org/10.1007/BF00705579

[13] Singhapakdi, A. and Vitell, S.J. (1990) Marketing Ethics: Factors Influencing Perceptions of Ethical Problems and Alternatives. Journal of Macromarketing, 10, 4-18. http://dx.doi.org/10.1177/027614679001000102

[14] Zeng, F.E., Luo, X., Tu, C.X. and Li, P. (2011) Online Consumer Unethical Behavior: Characteristics, Dimensions and Measurement. Nankai Business Review, 14, 26-36. 
[15] Isenberg, D.J. (1986) Group Polarization: A Critical Review and Meta-Analysis. Journal of Personality and Social Psychology, 50, 1141-1151. http://dx.doi.org/10.1037/0022-3514.50.6.1141

[16] Lee, E.J. (2007) Deindividuation Effects on Group Polarization in Computer-Mediated Communication: The Role of Group Identification, Public-Self-Awareness, and Perceived Argument Quality. Journal of Communication, 57, 385403. http://dx.doi.org/10.1111/j.1460-2466.2007.00348.x

[17] Postmes, T. and Spears, R. (1998) Deindividuation and Antinormative Behavior: A Meta-Analysis. Psychological Bulletin, 123, 238-259. http://dx.doi.org/10.1037/0033-2909.123.3.238

[18] Roman, S. (2007) The Ethics of Online Retailing: A Scale Development and Validation from the Consumers’ Perspective. Journal of Business Ethics, 72, 131-148. http://dx.doi.org/10.1007/s10551-006-9161-y

[19] Muncy, J.A. and Vitell, S.J. (1992) Consumer Ethics: An Investigation of the Ethical Beliefs of the Final Consumer. Journal of Business Research, 24, 297-311. http://dx.doi.org/10.1016/0148-2963(92)90036-B

[20] Vitell, S.J. and Muncy, J. (2005) The Muncy-Vitell Consumer Ethics Scale: A Modification and Application. Journal of Business Ethics, 62, 267-275. http://dx.doi.org/10.1007/s10551-005-7058-9

[21] Rawwas, M.Y. (2001) Culture, Personality and Morality: A Typology of International Consumers' Ethical Beliefs. International Marketing Review, 18, 188-211. http://dx.doi.org/10.1108/02651330110390006

[22] Hair, J.F., Tatham, R.L., Anderson, R.E. and Black, W. (2006) Multivariate Data Analysis. Pearson Prentice Hall, New York.

[23] Singhapakdi, A., Rawwas, M.Y., Marta, J.K. and Ahmed, M.I. (1999) A Cross-Cultural Study of Consumer Perceptions about Marketing Ethics. Journal of Consumer Marketing, 16, 257-272. http://dx.doi.org/10.1108/07363769910271496 